\title{
Peningkatan Kompetensi Guru : Membuat Soal HOTS dan Pengecoh Tipe Multiple Choice
}

\author{
Ena Suhena Praja ${ }^{1}$, Dina Pratiwi Dwi Santi ${ }^{2}$, Setiyani $^{3}$ \\ ${ }^{1,3}$ Pendidikan Matematika, Universitas Swadaya Gunung Jati Cirebon \\ ${ }^{2}$ PGSD, Universitas Swadaya Gunung Jati Cirebon \\ Email : ${ }^{1}$ enasuhenapraja@fkip-unswagati.ac.id, ${ }^{2}$ dinapratiwids@fkip-unswagati.ac.id, \\ ${ }^{3}$ setiyani@fkip-unswagati.ac.id
}

\begin{abstract}
Abstrak
Penyusunan soal berpikir tingkat tinggi (HOTS) masih belum dipahami dan dikuasai dengan baik oleh guru di SDN Sadagori 1 Kota Cirebon. Padahal kemampuan ini sangat penting untuk dimiliki setiap pendidik dalam rangka mempersiapkan siswa untuk menghadapi kompetisi pada abad 21. Soal HOTS tidak serta merta dapat dikuasai oleh siswa tanpa adanya stimulus yang diberikan. Oleh karena itu tujuan pelatihan ini adalah untuk memberikan pemahaman tentang ciri-ciri soal HOTS dari C4 - C6, strategi membuat pengecoh yang efektif/berfungsi, mengubah soal LOTS menjadi HOTS serta memberikan pengalaman langsung dalam membuat soal HOTS dan pengecohnya. Metode pelaksanaan PKM terdiri dari tiga tahap, yakni pendahuluan, solusi mitra, dan evaluasi. Pengabdian ini melibatkan 19 guru, 3 observer dan 2 pemateri. Pada saat pelatihan berlangsung, semua guru aktif dalam bertanya saat pemaparan materi maupun diskusi kelompok dalam membuat soal HOTS dan pengecohnya. Berdasarkan hasil observasi setiap 73opic73tor pencapaian berhasil dikuasai oleh guru. Kegiatan Pengabdian Kepada Masyarakat (PKM) ini disambut baik oleh seluruh guru dan kepala sekolah. Harapannya kegiatan ini dapat berkesinambungan dengan mengambil 73opic-topik atau isu yang sedang hangat dibidang Pendidikan.
\end{abstract}

Kata Kunci : Pengecoh, Kompetensi Guru, HOTS, Pilihan Ganda

\begin{abstract}
The preparation of high-order thinking questions (HOTS) is still not well understood and mastered by teachers at SDN Sadagori 1 Cirebon City. Even though this ability is very important for every educator to have in order to prepare students to face competition in the 21st century. HOTS questions cannot be mastered by students without any stimulus provided. Therefore, the aim of this training is to provide an understanding of the characteristics of HOTS questions from C4 - C6, strategies for making effective / functional distractors, changing LOTS questions to HOTS and providing direct experience in making HOTS questions and their distractors. The PKM implementation method consists of three stages, namely introduction, partner solutions, and evaluation. This service involved 17 teachers, 3 observers and 2 presenters. During the training, all the teachers were active in asking questions during the presentation of the material and in group discussions in making HOTS questions and their tricks. Based on the results of observations, each indicator of achievement has been mastered by the teacher. This Community Service Activity (PKM) was welcomed by all teachers and school principals. The hope is that this activity can be sustainable by taking topics or issues that are currently hot in the field of education.
\end{abstract}


Keywords: Cheater, Competence of The Teacher, HOTS, Multiple Choice

\section{PENDAHULUAN}

Keterampilan siswa dalam menyelesaikan soal sangat tergantung pada soal seperti apa yang biasanya oleh dikerjakan siswa. Sejak kurikulum 2013 mulai diterapkan, soal-soal yang diberikan pada siswa harus mengacu pada higher order thinking skills (HOTS). Hal ini menjadi tuntutan sekaligus tantangan bagi semua guru di setiap jenjang Pendidikan untuk merubah paradigma membuat soal dari Lower Order Thinking Skills (LOTS) beralih ke HOTS. Tujuannya adalah membekali siswa dengan pencapaian kompetensi abad 21 yang terdiri dari kemampuan berkolaborasi, berpikir kritis, kreatif dan komunikatif [1]. Kompetensi tersebut dapat tercapai apabila dalam proses kegiatan belajar mengajar dan penilaian memfokuskan pada terwujudnya kemampuan HOTS.

HOTS merupakan kemampuan berpikir siswa tingkat tinggi yang meliputi kemampuan analisis, evaluasi, dan mengkreasi [2]. Seorang siswa dikatakan memiliki kemampuan analisis apabila dia mampu mengidentifikasi pertanyaan, membedakan faktor sebab dan akibat dari sebuah soal yang rumit, serta menganalisis informasi yang diterima untuk kemudian dikenali bagaimana pola atau hubungannya. Seorang siswa dikatakan memiliki kemampuan evaluasi apabila dia mampu memberikan peniliaan terhadap suatu gagasan, membuat hipotesis dan mengujinya berdasarkan kriteria yang ditetapkan. Seorang siswa dikatakan memiliki kemampuan kreasi/mencipta apabila dia mampu membuat generalisasi dari suatu ide, merancang cara untuk menyelesaikan masalah, dan mengorganisasikan bagian-bagian menjadi struktur baru yang belum ada sebelumnya [3]. Beberapa kemampuan tersebut bukanlah kemampuan yang berkembang dengan sendirinya melainkan harus dilatih melalui pemberian stimulus berupa soal-soal non rutin yang mengarah pada beberapa kriteria HOTS [4].

Perkembangan Informasi dan Teknologi pada abad 21 serta penerapan kurikulum 2013 tidak secara langung meningkatkan ranking siswa Indonesia pada TIMSS dan PISA. Tahun 2015 Indonesia menduduki peringkat ke-64 dari 72 negara yang berpatisipasi pada PISA, dan menduduki peringkat ke-45 dari 48 negara yang berpatisipasi pada TIMSS [5]. Tahun 2018, peringkat Indonesia turun dibandingkan tahun 2015. Untuk kategori matematika, Indonesia berada di peringkat ke 73 yaitu 7 dari bawah dengan skor rata-rata 379. Peringkat 1 masih diduduki China dengan skor rata-rata 591 [6]. Berdasarkan hasil tersebut menjadi sebuah keharusan untuk membekali siswa dengan kemampuan HOTS dalam proses pembelajaran.

Berdasarkan fakta di lapangan pembuatan soal HOTS tidaklah mudah terutama bagi guru pada jenjang Pendidikan dasar. Tim Pengabdian Kepada Masyarakat (PKM) mengadakan survey awal pada sejumlah guru di SDN Sadagori 1 Cirebon terkait penguasaan konsep HOTS dengan memberikan link google form https://forms.gle/kcvRo29bzh6BYqqS6. Berdasarkan hasil survey tersebut diperoleh hasil sebanyak 21\% atau 4 dari 19 guru SD yang tepat memahami apa itu HOTS. Sebanyak $16 \%$ guru yang memahami definisi HOTS, dan 11 $\%$ guru yang dapat membuat soal HOTS. Seluruh responden yang berjumlah 19 guru (100\%), sepakat bahwa soal HOTS perlu dikembangkan untuk mempersiapkan dan membekali siswa dalam menghadapi kompetisi di abad 21.

Adapun salah satu contoh hasil survey pendahuluan dapat dilihat pada Gambar 1 berikut. 


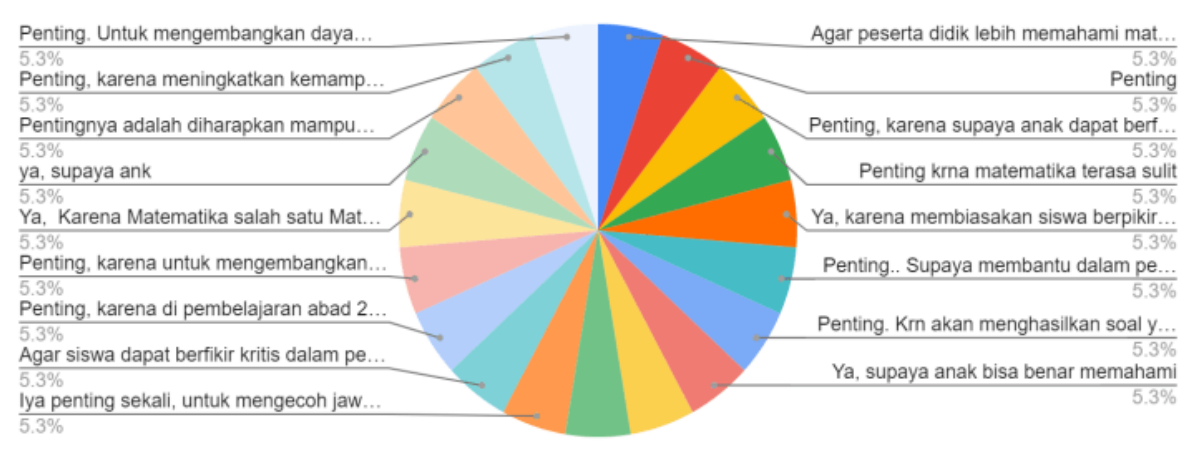

Gambar 1 Pentingnya Penguasaan Soal HOTS

Berdasarkan hasil wawancara tidak terstruktur, beberapa guru di SDN Sadagori 1 mengalami kesulitan dalam membuat soal HOTS terutama pada tes yang bersifat objektif. Tes objektif seperti tipe pilihan ganda memiliki satu jawaban yang benar sedangkan yang lainnya disebut pengecoh atau distractor. Selain membuat pokok soal, guru-guru juga harus memikirkan bagaimana membuat pengecoh yang akan mengecoh siswa. Keadaan pengecoh soal ini secara tidak langsung dapat melatih siswa untuk berpikir kritis. Apabila setiap butir soal dijawab benar oleh seluruh siswa maka hal ini mengindikasikan pengecoh soalnya tidak berfungsi. Oleh karena itu butir soal pilihan ganda dapat dikategorikan memiliki kualitas yang baik apabila keseluruhan distractornya berfungsi [7].

Melihat hasil survey awal dan wawancara tidak terstruktur yang telah kami lakukan, maka kami tim PKM Universitas Swadaya Gunung Jati (UGJ) berkolaborsi dengan SDN Sadagori 1 Cirebon sebagai mitra menyelenggarakan pelatihan dan pendampingan pembuatan soal HOTS dan pengecoh tipe multiple choice. Sehingga, diharapkan kompetensi guru-guru di SDN Sadagori 1 Cirebon dalam menguasai konsep HOTS dapat meningkat. Selain itu, dapat diketahui persentase jumlah guru yang mampu membuat soal HOTS dan pengecoh soal tipe multiple choice untuk level kognitif $\mathrm{C} 4, \mathrm{C} 5$, dan $\mathrm{C} 6$.

\section{METODE}

Pengabdian ini diselenggarakan di SDN Sadagori 1 Cirebon dalam rangka meningkatkan kompetensi guru-guru di SDN Sadagori 1 Cirebon dalam menguasai konsep HOTS. Selain itu, dapat diketahui persentase jumlah guru yang mampu membuat soal HOTS dan pengecoh soal tipe multiple choice untuk level kognitif C4, C5, dan C6. Seluruh peserta PKM yang mengikuti kegiatan ini berjumlah 19 orang yang notabene adalah guru di SDN Sadagori 1 Cirebon.

Pengabdian yang dilaksanakan menggunakan metode ceramah, tanya-jawab, diskusi, dan penugasan pada saat pelatihan dan pendampingan pembuatan soal HOTS dan pengecoh tipe multiple choice. Tanya-jawab merupakan metode yang digunakan untuk menggali pengetahuan peserta pengabdian, baik yang tidak diketahui maupun yang belum dipahami [8]. Sedangkan tahapan pada pengabdian ini melalui empat tahap dimulai dari proses analisis sampai dengan penentuan target luaran seperti terlihat pada Diagram Alur sebagai berikut. 


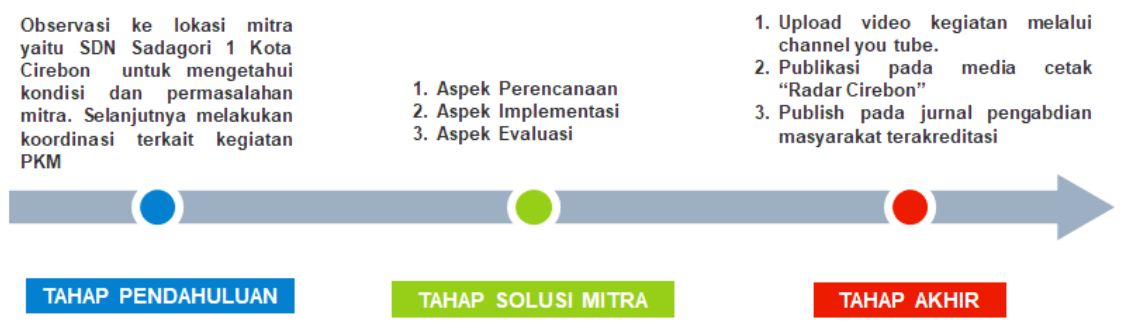

Gambar 2 Tahapan Pengabdian Kepada Masyarakat (PKM) PKM.

Berikut adalah deskripsi secara lengkap aktivitas yang dilakukan pada setiap tahapan

1. Tahap Pendahuluan

Tim melakukan observasi ke lokasi mitra yaitu SDN Sadagori 1 Kota Cirebon dengan tujuan mengetahui kondisi dan permasalahan yang dihadapi oleh mitra seperti minimnya pengetahuan guru dalam membedakan soal LOTS dan HOTS serta kesulitan dalam membuat pengecoh soal pilihan ganda. Selanjutnya tim melakukan koordinasi untuk melaksanakan kegiatan PKM, menentukan waktu dan pelaksanaan

2. Tahap Solusi Permasalahan Mitra

Setelah observasi ke tempat mitra PKM, tim pengabdi merencanakan pelatihan pengembangan soal HOTS dan pengecoh pada soal pilihan ganda. Tim PKM mempersiapkan beberapa instrumen untuk melihat ketercapaian proses dan hasil. Instrumen yang disiapkan adalah lembar observasi dan beberapa soal terkait kemampuan guru dalam menguasai konsep HOTS. Adapun tahap dari permasalahan solusi permasalahan mitra yang ditawarkan dalam PKM ini terdiri dari aspek perencanaan, implementasi, dan evaluasi. Solusi dari permasalahan aspek perencanaan yang ditawarkan dalam pengabdian ini yaitu sebagai berikut: pendampingan guru dalam mengklasifikasikan soal LOTS dan HOTS. Solusi dari permasalahan aspek implementasi di antaranya: memberikan pelatihan dalam membuat beberapa soal HOTS, memberikan pelatihan mengubah soal LOTS menjadi HOTS, memberikan pelatihan bagaimana cara membuat pengecoh pada soal pilihan ganda. Solusi dari permasalahan aspek evaluasi yang ditawarkan dalam PKM ini sebagai berikut: melakukan refleksi terhadap hasil pelatihan yang telah dilaksanakan, melihat respons peserta terhadap peningkatan kompetensi guru dalam membuat soal HOTS dan pengecoh tipe Multiple Choice.

3. Tahap Akhir

Pada tahap akhir, difokuskan pada target luaran PKM. Adapun beberapa target luaran PKM "Peningkatan Kompetensi Guru : Membuat Soal HOTS dan Pengecoh Tipe Multiple Choice" di antaranya: upload video kegiatan melalui channel youtube, publikasi pada media cetak "Radar Cirebon" dan publish pada jurnal pengabdian masyarakat.

Guru-guru di SDN Sadagori 1 Cirebon diberikan soal tes di awal (sebelum pelaksanaan pelatihan dan pendampingan) dan tes akhir (setelah pelaksanaan pelatihan dan pendampingan. Soal tersebut merupakan instrumen yang digunakan untuk mengukur peningkatan kompetensi guru-guru di SDN Sadagori 1 Cirebon dalam menguasai konsep HOTS yakni menyebutkan kepanjangan dari HOTS, menyebutkan definisi HOTS, urgensi HOTS, dan membuat soal HOTS. Rumus untuk menghitung peningkatan [9] adalah:

$$
\text { Peningkatan }=\text { selisih rata-rata tes akhir dengan tes awal }
$$

Sedangkan instrumen yang digunakan untuk mengetahui kemampuan guru dalam membuat soal HOTS dan pengecoh soal tipe multiple choice untuk level kognitif C4, C5, dan C6 adalah lembar observasi. Instrumen tersebut disusun dengan pilihan jawaban mampu/tidak 
untuk setiap pernyataan yang diberikan. Sedangkan untuk menghitung persentase jumlah guru yang mampu membuat soal HOTS dan pengecoh soal tipe multiple choice untuk level kognitif $\mathrm{C} 4, \mathrm{C} 5$, dan $\mathrm{C} 6$ dapat menggunakan rumus:

$$
\text { Persentase }(\%)=\frac{\sum \text { Guru yang mampu membuat soal HoTS dan pengecohnya }}{\sum \text { seluruh guru }} \times 100 \%
$$

\section{HASIL DAN PEMBAHASAN}

Rangkaian kegiatan pelatihan pembuatan soal HOTS dan pengecohnya pada tipe soal pilihan ganda dalam rangka peningkatan kompetensi guru diawali pada tahap pendahuluan tanggal 28 Januari 2021. Pada tahap pendahuluan diperoleh beberapa masalah mitra di antaranya: penguasaan konsep HOTS yang masih minim, kesulitan guru dalam membuat pengecoh yang berfungsi serta kesulitan guru dalam membedakan soal LOTS dan HOTS. Selanjutnya tim PKM melakukan koordinasi dengan kepala sekolah untuk menentukan waktu dan tempat pelaksanaan pelatihan dan pendampingan.

Pada tahap solusi mitra terbagi menjadi tiga kegiatan yaitu kegiatan perencanaan, implementasi dan evaluasi. Kegiatan perencanaan dilaksanakan pada tanggal 22 Februari 2021. Tim PKM dan mitra (sekolah) melakukan fixasi terkait sarana dan prasarana yang akan digunakan, rundown acara serta materi yang akan disampaikan. Tim PKM juga mempersiapkan beberapa instrumen pengabdian seperti lembar observasi dan beberapa soal penguasaan konsep HOTS.

Selanjutnya kegiatan implementasi pelatihan dan pendampingan pembuatan soal HOTS dan pengecohnya pada tipe soal pilihan ganda untuk meningkatkan kompetensi guru dilaksanakan pada tanggal 24 Februari 2021. Kegiatan ini diikuti oleh 19 guru SDN Sadagori 1 yang terdiri dari guru kelas dan beberapa guru mata pelajaran. Untuk lebih jelasnya, peserta yang mengikuti kegiatan PKM dapat dilihat pada Gambar 3 berikut.

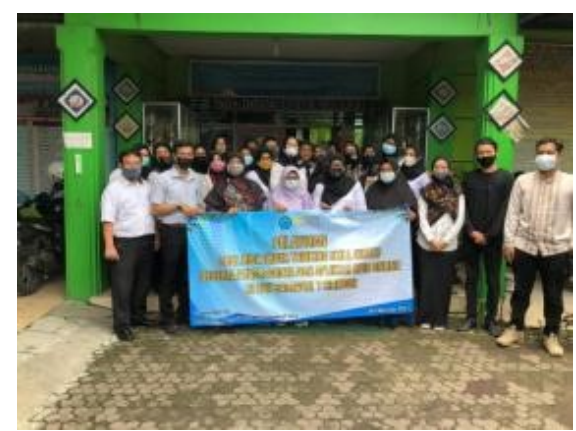

Gambar 3 Peserta PKM Pembuatan Soal HOTS dan Pengecohnya di SDN Sadagori 1 Kota Cirebon

Pada awal acara tim menyampaikan pemahaman konsep tentang HOTS di antaranya adalah: pengertian HOTS, mengapa HOTS dikembangkan, karakteristik soal HOTS dan langkah menyusunnya. Selain disampaikan konsep HOTS, guru juga belajar bagaimana membuat pengecoh yang efektif, memprediksi jawaban siswa dari berbagai kemungkinan, dan merumuskan kriteria pengecoh yang efektif. Berikut dokumentasi saat pemateri menyampaikan pemahaman konsep tentang HOTS dan pengecohnya: 

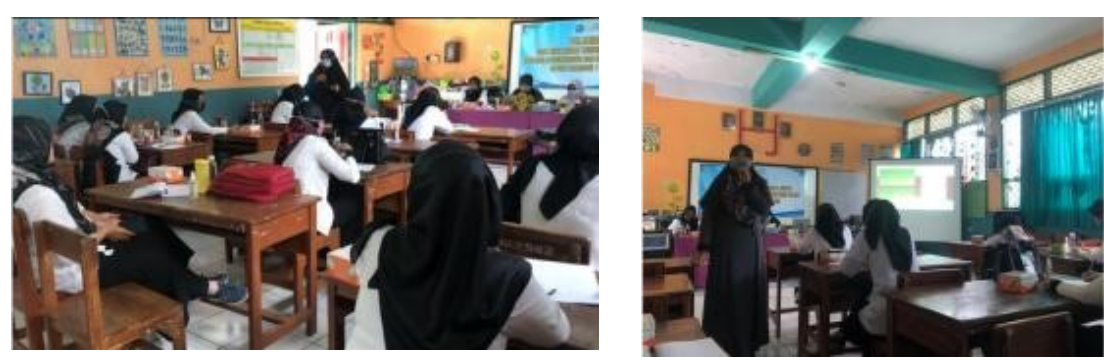

Gambar 4 Pemateri Menyampaikan Konsep tentang HOTS dan Pengecohnya

Materi tidak hanya disampaikan melalui metode ceramah, namun peserta pengabdian diberikan kesempatan untuk melakukan tanya-jawab, berdiskusi, dan diberikan tugas untuk membuat soal HOTS dan pengecohnya. Selama pelaksanaan pelatihan, beberapa observer mengamati bagaimana guru membuat soal dalam kelompok. Dokumentasi kerja kelompok guru dapat dilihat pada Gambar 5 berikut.
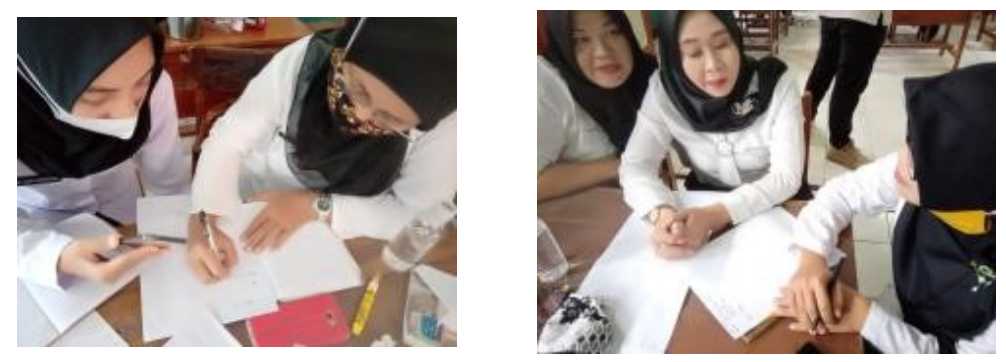

Gambar 5 Kerja Kelompok Guru dalam Pembuatan HOTS dan Pengecohnya

Pada saat kerja kelompok, peserta aktif berdiskusi, saling menanggapi dan pemateri intens terlibat dalam diskusi kelompok. Antusias peserta semakin meningkat karena metode yang digunakan hands on learning melalui praktik pembuatan soal langsung. Rekapitulasi pencapaian hasil kerja kelompok dalam membuat soal HOTS dan pengecohnya dapat dilihat pada Tabel 1 berikut.

Tabel 1 Rekapitulasi Observasi Peserta

\begin{tabular}{|c|l|c|}
\hline Nomor & \multicolumn{1}{|c|}{ PERNYATAAN } & Mampu/Tidak \\
\hline 1 & $\begin{array}{l}\text { Mampu membuat soal HOTS dan pengecohnya pada } \\
\text { level kognitif C-4 (Menganalisis) }\end{array}$ & $100 \%$ \\
\hline 2 & $\begin{array}{l}\text { Mampu membuat soal HOTS dan pengecohnya pada } \\
\text { level kognitif C-5 (Mengevaluasi) }\end{array}$ & $81.25 \%$ \\
\hline 3 & $\begin{array}{l}\text { Mampu membuat soal HOTS dan pengecohnya pada } \\
\text { level kognitif C-6 (Mengkreasi) }\end{array}$ & $68.75 \%$ \\
\hline
\end{tabular}

Berdasarkan Tabel 1, semua guru mampu membuat soal HOTS dan pengecohnya untuk level kognitif C-4 yaitu menganalisis sedangkan pada level C-6 guru masih kesulitan dalam membuatnya. Hal ini disebabkan karena guru kesulitan menyajikan soal HOTS level C-6 dalam tipe pilihan ganda. Akan lebih mudah apabila soal mengkreasi disajikan dalam bentuk uraian. Oleh karena itu perlu pembiasaan dalam membuat soal level C-6. Kesulitan dalam membuat soal C-6 juga dialami oleh guru lulusan prodi Pendidikan kimia UNY dengan rincian kemampuan membuat soal $\mathrm{C} 4$ sebesar $13,2 \%$; C5 sebesar $0,7 \%$ dan $\mathrm{C} 6$ sebesar $0,0 \%$ [10]. 
Adapun peningkatan kemampuan guru dalam menguasai konsep HOTS antara sebelum dan sesudah pelatihan dapat dilihat pada diagram berikut :

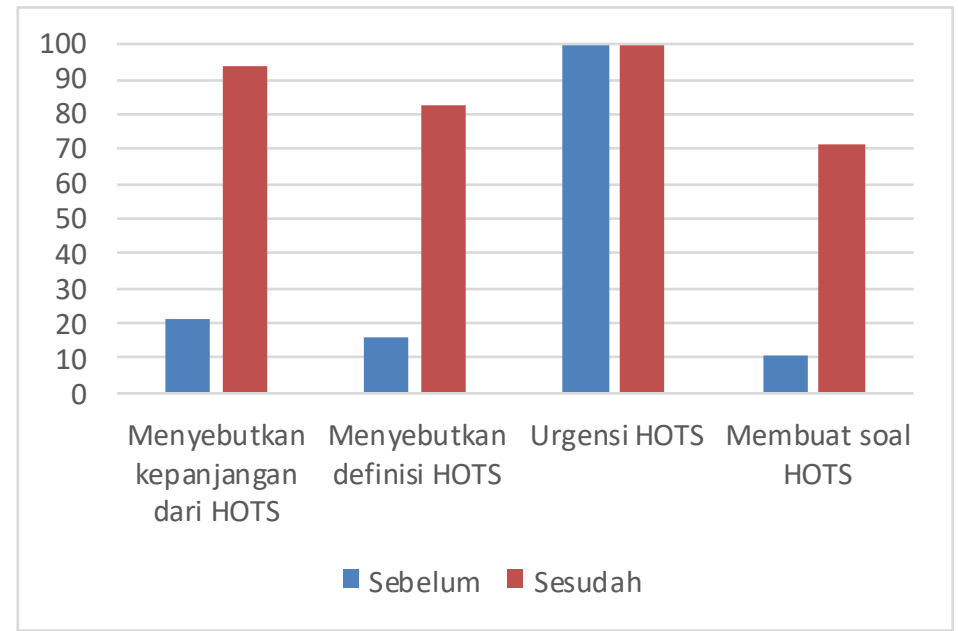

Gambar 5 Peningkatan Kemampuan Guru dalam membuat Soal HOTS dan Pengecohnya

Sebagai luaran tambahan dari kegiatan PKM, tim bekerjasama dengan Kabar Cirebon untuk memuat berita di harian cetak dan elektronik. Berita PKM tersebut terbit pada hari Senin tanggal 1 Maret 2021 dengan judul Tingkatkan Kreativitas, Dosen FKIP UGJ Berikan Pelatihan Guru SD. Luaran tersebut ditampilkan seperti yang dapat dilihat di bawah ini.

\section{Tingkatkan Kreativitas, Dosen FKIP UGJ Berikan Pelatihan Guru SD}

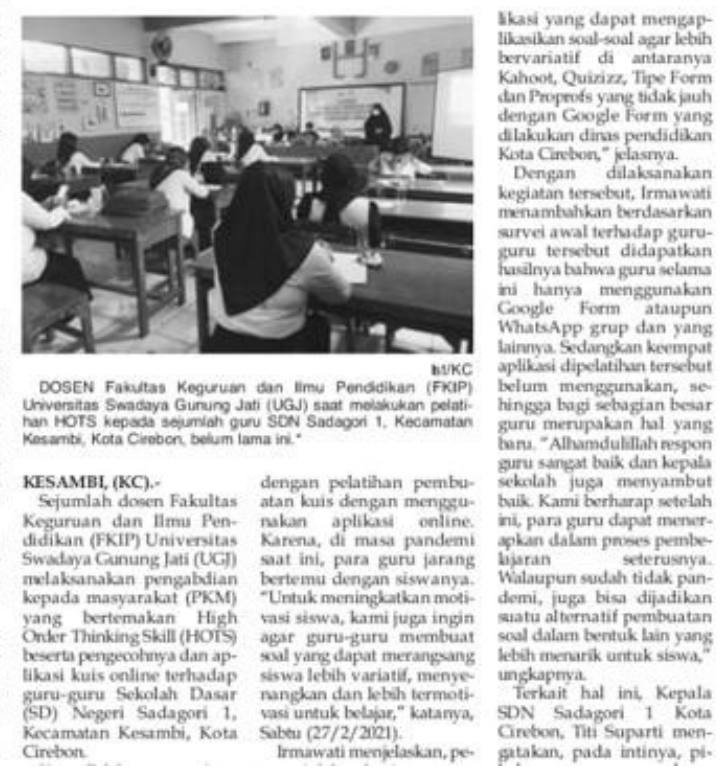

Gambar 6 Luaran Tambahan 


\section{KESIMPULAN DAN SARAN}

Berdasarkan hasil kegiatan PKM pembuatan soal HOTS dan pengecohnya diperoleh kesimpulan bahwa (1) terdapat peningkatan kemampuan guru-guru di SDN Sadagori 1 Kota Cirebon dalam meguasai konsep HOTS dan (2) rata-rata persentase jumlah guru yang mampu membuat soal HOTS dan pengecoh soal tipe multiple choice untuk level kognitif $\mathrm{C} 4$, C5, dan C6 adalah 83,33\%. Selain itu, peserta PKM sangat antusias mengikuti pelatihan, terlibat aktif dalam bertanya maupun diskusi kelompok, dan mempunyai keinginan untuk berlatih secara mandiri. Kegiatan PKM yang telah dilaksanakan memberikan pengalaman dan menambah pengetahuan khususnya bagi guru SDN Sadagori 1. Harapan dari guru-guru, agar pelatihan seperti ini dapat berkesinambungan dengan mengambil topik-topik atau isu yang sedang hangat di bidang Pendidikan

\section{UCAPAN TERIMAKASIH}

Tim PKM mengucapkan terimakasih kepada Lembaga Pengabdian Masyarakat (LPM) Univeritas Swadaya Gunung Jati yang telah memberikan hibah dan keluarga besar SDN Sadagori 1 Kota Cirebon.

\section{DAFTAR PUSTAKA}

[1] Maksum, A., \& Suntari, Y. (2019). Pelatihan Penyusunan Soal Ips Berbasis Hots. Jurnal Pemberdayaan Sekolah Dasar (JPSD), 2(1), 10-13.

[2] Ichsan, I. Z., Sigit, D. V., Miarsyah, M., Ali, A., Arif, W. P., \& Prayitno, T. A. (2019). HOTS-AEP: Higher Order Thinking Skills from Elementary to Master Students in Environmental Learning. European Journal of Educational Research, 8(4), 935-942.

[3] Suryapuspitarini, B. K., Wardono, W., \& Kartono, K. (2018). Analisis soal-soal matematika tipe Higher Order Thinking Skill (HOTS) pada kurikulum 2013 untuk mendukung kemampuan literasi siswa. PRISMA, Prosiding Seminar Nasional Matematika, 1, 876-884.

[4] Atmojo, I., Sunarno, W., \& Ashadi, M. (2017). Profile of elementary school pre-service teacher based on high order thinking skills (HOTS) on natural science subject. International Conference on Teacher Training and Education 2017 (ICTTE 2017).

[5] Nugroho, R. A. (2018). HOTS (Kemampuan Berpikir Tingkat Tinggi: Konsep, Pembelajaran, Penilaian, dan Soal-soal). Jakarta: PT Gramedia Widiasarana Indonesia.

[6] Tohir, M. (2019). Hasil PISA Indonesia tahun 2018 turun dibanding tahun 2015.

[7] Tarmizi, P., Setiono, P., Amaliyah, Y., \& Agrian, A. (2021). Analisis Butir Soal Pilihan Ganda Tema Sehat Itu Penting Kelas V SD Negeri 04 Kota Bengkulu. ELSE (Elementary School Education Journal): Jurnal Pendidikan Dan Pembelajaran Sekolah Dasar, 4(2), 124-132.

[8] Santi, D. P. D., Setiyani, S., \& Asnawati, S. (2020). PEMBERDAYAAN ORANG TUA SISWA TK ANNUR KABUPATEN CIREBON MELALUI KETERAMPILAN RAJUT TANGAN DAN ACCESS MARKET. Al-Khidmat, 3(2), 42-50.

[9] Santi, D. P. D., Sulaiman, H., \& Kurnia, M. D. (2020). KEMAMPUAN GURU DALAM PEMBELAJARAN MATEMATIKA MELALUI PEMANFAATAN MEDIA BUKU POP UP DI SLB TUNAGRAHITA KABUPATEN CIREBON. Prosiding, 9(1). 
[10] Iskandar, D., \& Senam, S. (2015). Studi kemampuan guru kimia sma lulusan UNY dalam mengembangkan soal UAS berbasis HOTS. Jurnal Inovasi Pendidikan IPA, 1(1), $65-72$. 